\title{
The Trade Potential of Pakistan: An Application of the Gravity Model
}

\author{
Nazia Gul* and Hafiz M. Yasin ${ }^{* *}$
}

\begin{abstract}
This paper attempts to estimate Pakistan's trade potential, using the gravity model of trade. Panel data for the period 1981-2005 across 42 countries is employed in the analysis. The coefficients obtained from the model are then used to predict the country's trade potential worldwide as well as within specific trading regions. The results reveal that Pakistan's trade potential is highest with countries in the Asia-Pacific region (the Association of Southeast Asian Nations [ASEAN]), the European Union (EU), the Middle East, Latin America, and North America. Specifically, the maximum potential exists with Japan, Sri Lanka, Bangladesh, Malaysia, the Philippines, New Zealand, Norway, Sweden, Italy, and Denmark. Therefore, Pakistan should explore ways and means to further improve its trade relations with the countries concerned, and also concentrate on ASEAN, the Middle East, and the EU to increase its market share as far as possible. The volume of trade between Pakistan and other members of the South Asian Association for Regional Cooperation (SAARC) and Economic Cooperation Organization (ECO) is very low, despite the existence of significant potential. The main obstacles to this end are the political and social tensions among neighboring countries, particularly between Pakistan and India, which are the main players of SAARC. The same obstacles exist in the case of the EU and NAFTA, where Pakistani exports are adversely affected by political considerations.
\end{abstract}

Keywords: Trade potential, gravity model, Pakistan.

JEL Classification: F19, O16.

\section{Introduction}

Pakistan has recently witnessed a significant increase in exports as a result of rapid improvement in the international trading environment. During 2002/03 to 2005/06, Pakistan's exports remained at 16 percent of gross domestic product (GDP) per annum, while imports remained at 29

\footnotetext{
* Research Officer at the Economic Advisor's Wing, Finance Division, Government of Pakistan, Islamabad.

${ }^{* *}$ Associate Professor at the International Islamic University, Islamabad.
} 
percent of GDP on average. Pakistan has adopted an export-led growth strategy since 2000/01 and the success of this strategy obviously requires that Pakistan have greater access to international markets for its products. The government has started negotiating several bilateral and regional trade agreements with neighboring countries. However, despite the importance of regional trade and the government's serious efforts, the volume of Pakistan's trade within SAARC and ECO is not up to the mark. The primary reasons for low trade within the region are obviously the political and military tensions that have prevailed among the major players for decades, and the protectionist policies adopted by the nations concerned. If the members succeed in removing the tariff and nontariff barriers as visualized by the SAARC charter, all countries of the region, including Pakistan, will reap the benefits of intra-regional trade.

The present study attempts to estimate Pakistan's overall trade potential with its traditional partners and other important countries by using panel data estimation. Further, keeping in view the importance of the implementation of the South Asian Free Trade Agreement (SAFTA) 2006, the study analyzes the extent of SAARC's integration into the world economy in general and for Pakistan in particular. The results are expected to provide useful insights into the trading capacity of Pakistan and help identify new areas for exploration.

The paper is organized as follows. We discuss the theoretical foundations of the gravity model in the following section. Section 3 provides a general overview of the application of this model. Here, we review some important studies on trade potential and the impact of regional trading arrangements on trade flows. Section 4 presents the model and discusses the methodology, while Section 5 discusses the data used in the estimation. Section 6 presents the primary results of the gravity model and Section 7 uses the estimated values of parameters to compute the trade potential of Pakistan. The last section presents conclusions and policy implications.

\section{Theoretical Foundations}

The gravity model derives from Newton's Law of Universal Gravitation and Bergen (1962) and Poyhonen (1963) pioneered the use of this concept in the area of international trade. According to the model, the volume of trade between two countries, like the gravitational force between two objects, depends directly on their respective 'masses' (where GDP is often used as a proxy for mass) and inversely on the distance 
between them (which captures the transportation costs). The gravity equation thus derived can be expressed as:

$$
F=G \frac{m_{1} \cdot m_{2}}{r^{2}} \Rightarrow \text { Trade }_{i j}=\alpha \cdot \frac{G D P_{i} \cdot G D P_{j}}{\text { Distance }_{i j}}
$$

This equation is often transformed into linear form so that it conforms to the usual regression analysis:

$$
\log \left(\text { Trade }_{i j}\right)=\alpha+\beta_{1} \log \left(G D P_{i} \cdot G D P_{j}\right)+\beta_{2} \log \left(\text { Distance }_{i j}\right)+u_{i j}
$$

The classical application of the model is provided in Linnemann (1966), who added an additional variable to the model to reflect the commodity composition of the trade flows. The model was modified by Leamer (1974) for two-digit Standard International Trade Classifications (SITC) for commodities, and includes separate measures of relative factor endowments as independent variables to determine the impact of income and population. Although the gravity model of trade has been an empirical success, its theoretical justification has been subject to some controversy. Attempts have been made to explore its connections with the key elements of trade theory. These attempts are more recent, and are reviewed below.

Anderson (1979) was the first to apply utility functions (CobbDouglas and Constant Elasticity of Substitution) to derive the gravity model using the properties of linear expenditure systems (LES). It is an alternative method of carrying out cross-section budget studies and one with potentially important efficiency properties. However, its use is limited to countries where the preference for traded goods is similar and where taxation structures and transportation costs are also comparable.

Bergstrand (1985) applied CES preferences and generalized the gravity model by introducing prices. In another attempt, Bergstrand (1989) applied the monopolistic competition model and assumed that goods are differentiated among firms rather than countries. He offered an analytical framework for understanding the gravity equations, which is consistent with modern theories of inter-industry and intra-industry trade. A general equilibrium model of international trade was developed to illustrate how the gravity equation complies with the Heckscher-Ohlin model of inter-industry trade and/or the Helpman-Krugman-Markusen models of intra-industry trade. It should be noted that Helpman and 
Krugman (1985) derived the gravity model under the assumption of increasing returns to scale in production. Bergstrand (1990) further extended the microeconomic foundations for a generalized gravity model to incorporate differences in the relative factor endowment and nonhomothetic preferences.

Anderson and van Wincoop (2001, 2003) have provided a general understanding of how border barriers affect trade and welfare in the context of the simple gravity model. They derive the gravity equation using the properties of market clearance and the CES structure of demand.

\section{Applications of the Model}

\subsection{An Overview}

Clarete et al. (2000) use the gravity model of bilateral trade to evaluate the effect of different preferential trading arrangements (PTAs) in the Asia-Pacific region. They use cross-section and panel data estimation techniques. Besides considering the basic determinants of the gravity model (GDP, distance, population, etc), they introduce dummies to measure the impact of PTAs on the trade of countries in the AsiaPacific region. Their findings indicate that PTAs have contributed significantly to trade expansion both at the global and regional level. The study provides evidence that PTAs can create rather than divert trade.

Boris and Vedran (2002) discuss the level of trade integration within the southeast Europe (SEE) region, using simple tools such as the trade openness ratio and trade concentration indices. The authors conclude that the target trade potential for Croatia lies within the EU and Central Europe Free Trade Agreement (CEFTA) countries. Therefore, any further liberalization of trade with the SEE countries should be accompanied by similar considerations for EU and CEFTA countries.

Using panel data estimation techniques, Rehman (2003) applies the generalized gravity model to analyze the trade of Bangladesh with its major partners. The results show that Bangladesh's trade is positively determined by the size of economies, per capita gross national product (GNP) differential of the countries involved, and openness of the trading countries.

Konkhartchank and Maurel (2003) examine the impact of institutions on trade, and estimate the potential of trade between the 
Commonwealth of Independent States (CIS), ${ }^{1}$ central eastern European countries, and EU via the gravity model. They find that CIS trade is still characterized by a very large trade destruction effect, which implies that trade with EU countries could increase in the long run provided that the said effect is minimized. They conclude that trade reinforcing/trade openness will have a positive impact on growth only if institutions can create an environment conducive to safe and secure exchange and ensure that trade is attractive to and profitable for all parties.

Batra (2004) analyzes India's global trade potential by applying the augmented gravity model and using ordinary least squares (OLS) techniques. The model is used first to analyze international trade flows and then to estimate the trade potential of India with its partners. In addition to the primary variables, income and distance, the model is augmented by several conditioning variables that affect trade. The study indicates that India has maximum trade potential in the Asia-Pacific region, followed by Western Europe and North America. The highest potential for expansion of trade exists with China, the UK, Italy, and France, provided that certain barriers and constraints are removed. The results show that India could potentially attain ten times or more the level of existing trade with certain other countries, including Central Asian states such as Georgia, Turkmenistan, and Uzbekistan.

Helmers and Pasteels (2005) use 'TradeSim' (the third version of a gravity model software) to calculate the trade potential for developing countries and economies in transition. They show how gravity models can be specifically designed and applied.

Rehman et al. (2006) apply the augmented gravity model to identify trade creation and trade diversion effects originating from the SAARC Preferential Trading Agreement (SAPTA) and the other nine members of the Regional Trade Agreement (RTA). While using the panel data approach with country pair-specific and year-specific fixed effects, they note the expected signs for all the usual gravity variables and dummies. They find a significant intra-bloc export creation effect in SAPTA, but there is evidence of a net export diversion effect as well. Their results show that Bangladesh, India, and Pakistan are expected to gain from joining the RTA.

1 The CIS comprises 11 countries: Armenia, Azerbaijan, Belarus, Kazakhstan, Kyrgyzstan, Moldova, Russia, Tajikistan, Turkmenistan, Ukraine, and Uzbekistan. 


\subsection{Studies on Pakistan}

There are only a few studies on Pakistan that use the gravity model. Here, we briefly discuss their main findings.

Khan (2000) estimates the gravity model to establish a relationship between bilateral trade in Pakistan and economic, geographical, and cultural factors. The trade volume (exports and imports of ten major commodities) is taken as the dependant variable. The explanatory variables are the real exchange rate, tariffs, distance, product of GNPs, product of per capita GNPs, official language (English), bordering country, and dummies to represent SAARC, ASEAN, NAFTA, and the EU. The model includes 21 countries and uses data for 1985, 1990, and 1994, covering ten commodities. All the variables are found to be highly significant except the variable for the bordering country, which is negative. This can be attributed to the historical conflict between India and Pakistan.

Another study conducted by the State Bank of Pakistan (2005) estimates a gravity model at the sectoral level. The value of exports is used as the dependant variable and several dummies are included to capture the effects of a common border, tariffs, common language, conflict, and geographical location, etc. The dataset covers 15 sectors for the years 2002 and 2003 to examine the trade potential of Pakistan with selected trading partners. The results indicate significant scope for expanding trade between Pakistan and India. According to the report, the true trade potential could have been far greater had both countries not engaged in conflicts, or had tariff and nontariff barriers been kept low. The sectoral level analysis indicates the existence of high trade potential in textiles, leather products, chemicals, food, beverages, and tobacco products.

Similarly, in a study conducted by the World Bank, Baroncelli (2007) applies the gravity model to estimate the "peace dividend" from trade in the case of Pakistan-India relations, where confrontation has been the norm for the past 50 years. The model uses bilateral trade data for 166 countries for the period 1948-2000 to estimate the trade potential between the two countries. The model includes two specific dummies to capture the impact of (i) PTAs, and (ii) a significant militarized dispute between Pakistan and India in any given year. The results indicate that, in the absence of war, trade would have been $\$ 591$ million in 2000: a peace dividend of $\$ 474$ million as against the recorded trade of $\$ 117$ million for 
that year. Likewise, adding the peace dividend and RTA gains leads to a potential trade volume of $\$ 683$ million between Pakistan and India. The study concludes that the link between conflict and trade is negative and significant. It also confirms that the presence of systems of regional preference induces a higher flow of imports among partner countries.

\section{Rationale for Study}

As discussed in the introduction, Pakistan's exports are historically concentrated in a few products and directed towards a few countries. This situation could lead to severe instability in the trade sector. Pakistan's exports (mainly textiles) are directed toward the US, Germany, Japan, UK, Hong Kong, Dubai, and Saudi Arabia. The US is the single-largest export market for Pakistan, accounting for 26.4 percent of its exports, followed by the UK and Germany. Japan is fast vanishing as a destination for Pakistani exports: its share in total exports has been in decline for a decade, from 5.7 percent a decade ago to less than 1 percent last year (Pakistan Economic Survey for 2006/07). It seems clear that Pakistan needs to diversify its exports not only in terms of commodities but also in terms of markets for export stability. The case of imports follows a similar story. A brief picture of the factual position is given in Appendix-I.

Therefore, it is important to identify the countries or regions where Pakistan has high trade potential. This is the primary objective of the study. The testable hypothesis is whether the trade potential is high within the geographic region or outside. For this purpose, we use the gravity model (augmented) as our tool of analysis. It is obvious that, in South Asia, member countries could gain considerably more from unilateral trade liberalization than from the current SAPTA or proposed SAFTA. However, if tariff and nontariff barriers to trade among members are reduced further, then all these countries could experience welfare gains from the liberalization of bilateral trade. This could have a significant trade creation effect under SAPTA. The SAARC region would benefit substantially from regional integration and SAFTA, which is most likely to promote intra-regional trade. The gravity model can help evaluate the importance of SAFTA for the region as well as the extent of integration for SAARC into the world economy in general and for Pakistan in particular. 


\section{Analytical Framework}

As discussed briefly in Section 2, the gravity model derives from Newton's Law of Universal Gravitation (like several other laws and concepts that were specific to the physical sciences). According to the gravity concept, the volume of trade between two countries depends directly on their respective sizes (usually the economic size as reflected by GDP) and inversely on the distance between them (as a proxy for transportation costs). Bergen (1962) and Poyhonen (1963) pioneered the use of the gravity concept in economic relationships. The primitive model is shown in Equation (1) above, in which the value of bilateral trade is directly related to the product of the GDPs of the trading partners, and inversely related to the distance between the two. The log-linear version of the model, commonly used in analysis, has also been shown as Equation (2). However, the rudimentary form has been further augmented by researchers to focus on other determinants of bilateral trade. It is interesting to note that theory has followed practice in the case of the gravity model.

\subsection{Augmented Gravity Model}

In addition to the traditional variables, several other conditioning variables can be added to the gravity model to account for other factors affecting bilateral trade. For instance, the basic model might include GDP per capita in the partner countries as an additional argument. More complicated models might contain other explanatory variables, such as the absolute value of per capita income differentials (PCGDPD) and dummies for a common border (BORDER), common language (LANG), and common socioeconomic region (REGL), etc. As usual, the dummies can take values of units or zeros. A representative equation is as follows:

$$
\begin{aligned}
\log \left(\text { Trade }_{i j}\right)= & \alpha+\beta_{1} \log \left(G D P_{i} G D P_{j}\right)+\beta_{2} \log \left(\text { PCGDP }_{i} \cdot P C G D P_{j}\right)+\beta_{3} \log \left(\text { Distance }_{i j}\right) \\
& +\beta_{4}\left(\text { BORDER }_{i j}\right)+\beta_{5}\left(\text { LANG }_{i j}\right)+\beta_{6}(R E G L)+\beta_{7}(P C G D P D)+u_{i j}
\end{aligned}
$$

We intend to use the above equation/s or a variant in our analysis

with further extensions. (For a detailed description of the variables, see the appendix).

\subsection{Panel Data Framework}

Traditionally, classical gravity models have been expressed as single equations using cross-sectional data to estimate trade flows 
between a pair of countries for a particular period (one year). However, the panel data framework provides more useful information vis-à-vis single-equation models, and has become increasingly popular since it allows the study of a particular issue at multiple sites with periodical observations over a defined timeframe. Several estimation techniques have been used while using the panel data approach. In particular, the fixed effect and random effect models are the most prominent:

\section{a. The Fixed Effect Model (FEM)}

In the FEM, the intercept in the regression is allowed to differ among individual units in recognition of the fact that each cross-sectional unit might have some special characteristics of its own. Thus, the model can be written as:

$$
Y_{i t}=\beta_{1 i}+\beta_{2} X_{2 i t}+\beta_{3} X_{3 i t}+u_{i t}
$$

The subscript $i$ to the intercept term suggests that the intercepts across the individuals are different, but that each individual intercept does not vary over time. The FEM is appropriate in situations where the individual specific intercept might be correlated with one or more regressors (Gujrati, 2003). To take into account the differing intercepts, the use of dummy variables is the most common practice and, therefore, the specification is known as the least-squares dummy variable (LSDV) model, which can be written as:

$$
Y_{i t}=\alpha_{1}+\alpha_{2} D_{2 i}+\alpha_{3} D_{3 i}+\alpha_{4} D_{4 i}+\beta_{2} X_{2 i t}+\beta_{3 i t}+u_{i t}
$$

However, there is a disadvantage to the LSDV in that it consumes a number of degrees of freedom when the number of cross-sectional units is very large, since one has to introduce $\mathrm{N}$ dummies.

\section{b. Random Effect Model (REM) or Error Components Model (ECM)}

In contrast to the FEM, the REM assumes that the intercept of an individual unit is a random draw from a much larger population with a constant mean (Gujrati, 2003). The individual intercept is then expressed as a deviation from this constant mean value. The REM has an advantage over the FEM in that it is economical in terms of degrees of freedom, since we do not have to estimate $\mathrm{N}$ cross-sectional intercepts. The REM is appropriate in situations where the random intercept of each crosssectional unit is uncorrelated with the regressors. The basic idea is to start 
with Equation (5.a). However, instead of treating $\beta_{1 \mathrm{i}}$ as fixed, it is assumed to be a random variable with a mean value of $\beta_{1}$. Then the value of the intercept for individual entity can be expressed as:

$$
\beta_{1 i}=\beta_{1}+\varepsilon_{i} \text { where } \mathrm{i}=1,2, \ldots, \mathrm{n}
$$

The random error term is assumed to be distributed with a zero mean and constant variance:

Substituting (5.c) into (5.a), the model can be written as:

$$
\begin{aligned}
Y_{i t} & =\beta_{1}+\beta_{2} X_{2 i t}+\beta_{3} X_{3 i t}+\varepsilon_{i}+u_{i t} \\
& =\beta_{1}+\beta_{2} X_{2 i t}+\beta_{3} X_{3 i t}+w_{i t}
\end{aligned}
$$

The composite error term $w_{i t}$ consists of two components: $\varepsilon_{i}$ is the cross-sectional or individual-specific error component, and $u_{i t}$ is the combined time series and cross-sectional error component, given that $\varepsilon_{i}$ $\sim\left(0, \sigma_{\varepsilon}^{2}\right), X_{i t} \sim\left(0, \sigma^{2} \mathrm{u}\right)$, where $\varepsilon_{i}$ is independent of the $X_{i t}$ (Gujrati, 2003).

Generally, the FEM is held to be a robust method of estimating gravity equations, but it has the disadvantage of not being able to evaluate time-invariant effects, which are sometimes as important as time-varying effects. Therefore, for the panel projection of potential bilateral trade, researchers have often concentrated on the REM, which requires that the explanatory variables be independent of the $\varepsilon_{i}$ and $u_{i t}$ for all cross-sections ( $i, j$ ) and all time periods (t) (Egger, 2002). If the intention is to estimate the impact of both time-variant and invariant variables in trade potential across different countries, then the REM is preferable to the FEM (Ozdeser \& Ertac, 2010).

\subsection{Endogeneity Issue}

The commonly employed gravity model, as shown in Equation (3) above, has been criticized for a two-way causation between the dependent variable (trade volume) and explanatory variable (GDPs of the trading partners). This is referred to as an endogeneity issue that can lead to biased estimates (although the degree of bias is unknown). A plausible solution is to use an instrumental variable to proxy the size of the economy: population instead of GDP, for instance. However, the populations of trading partners are often heterogeneous. Another 
solution is to use the trade-GDP ratio as the dependent variable, but this leaves no scope for the GDPs to be used as explanatory variable. Yet another possible remedy is to use a simultaneous equation framework, which, when reduced, will lead to separate equations for both mutually dependent variables, which can be estimated using the generalized method of moments (GMM) technique or some other technique. However, this might also suffer from identification problems. In general, it is easy to find appropriate instruments that should be independent of the target variable and, at the same time, closely associated with the variable being replaced. Therefore, it seems advisable to confine ourselves to the general specification employed by numerous researchers and to set aside the endogeneity issue for the purposes of this paper.

\section{Sample Size and Data}

In order to estimate the trade potential of Pakistan, we follow a two-step procedure. First, we estimate the basic gravity model to determine the coefficients of Pakistan's trade flows with its trading partners. In continuation, we estimate the augmented gravity model by including other variables so as to evaluate their impact on trade. Finally, the estimated coefficients are used to evaluate Pakistan's trade potential in general and particularly in the presence of certain other regional groups.

We consider 42 countries (including Pakistan) from within different regional groups. These countries were selected keeping in view the importance of their trading relationships with Pakistan as well as the availability of data. We select three countries from SAARC: Bangladesh, India, and Sri Lanka; four countries from ASEAN: Indonesia, Malaysia, the Philippines, and Thailand; two countries from NAFTA: Canada and the US; and almost all countries from the EU: Belgium, France, Germany, Denmark, Italy, Sweden, Switzerland, Greece, the Netherlands, Portugal, Spain, and the UK. Likewise, we have included countries such as Egypt, Iran, Turkey, Kuwait, and Saudi Arabia from the Middle East; Australia, New Zealand, Japan, China, and Hong Kong from the Far East, and Argentina, Brazil, Chile, and Mexico from Central and South America in the analysis.

Annual data for the period 1981-2005 is considered, including Pakistan's exports to and imports from all other trading partners. This data was obtained from the Direction of Trade Statistics yearbook (various issues) published by the International Monetary Fund (IMF). 
Data on GDP, GDP per capita, exchange rates, total imports, and total exports were obtained from the World Development Indicators (2007) database. Likewise, data on the consumer price index (CPI) was obtained from the International Financial Statistics database. Data on distance $(\mathrm{km})$ between Islamabad (the capital of Pakistan) and the capital cities of other countries were obtained from www.indo.com/distance. A detailed discussion of the variables involved is given in Appendix-II.

\section{Results of Gravity Model}

Here, we discuss the results obtained from applying the gravity model to our panel data (on Pakistan's bilateral trade relations with its partners) with increasing detail at successive stages.

\subsection{Basic Gravity Model}

Specifically, we estimate Equation (2) (slightly modified for the REM) here, which is reproduced below for the time period $t=1981-2005$ and for a cross-section of 42 countries, including Pakistan (the $j_{\text {th }}$ country), which implies 41 pairs of cross-observations:

$$
\log \left(\text { Trade }_{i j}\right)_{t}=\beta_{1}+\beta_{2} \log \left(G D P_{i} \cdot G D P_{j}\right)_{t}+\beta_{3} \log \left(\text { Distance }_{i j}\right)_{t}+\omega_{i j t}
$$

The results are reported in Table- 1 below. Both the traditional variables (product of GDP and distance) are found to be significant. They are of reasonable magnitude and carry the expected signs. We can deduce from this that Pakistan's bilateral trade with the countries concerned will increase by 0.95 percent as the product of GDPs increases by 1 percent. Likewise, the coefficient of the distance variable implies that, when the distance (as a proxy for transportation cost) between Pakistan and its trading partner increases by 1 percent on average, bilateral trade decreases by 1.44 percent. Hence, both variables are theoretically consistent with the hypothesis of the gravity model in that Pakistan's trade is directly related to the economic size of the partners and inversely related to the distance between them. 
Table-1: Basic Gravity Model

\begin{tabular}{lccc}
\hline $\begin{array}{l}\text { Independent } \\
\text { Variable }\end{array}$ & Coefficient & $\begin{array}{c}\text { Standard } \\
\text { Error* }\end{array}$ & t-Statistic* \\
\hline Constant & -5.09 & 5.56 & -0.92 \\
Product of GDP & 0.96 & 0.04 & 22.06 \\
Distance & -1.45 & 0.67 & -2.17 \\
Adjusted R-squared & 0.50 & - & - \\
\hline
\end{tabular}

* The standard errors and t-statistics are hetroskedasticity-robust (White, 1980).

We also attempt to estimate the model by adding the product of per capita GDP of Pakistan's trading partners as an explanatory variable in addition to the primary variables (GDP and distance). However, the results are not encouraging. Although all three variables are statistically significant and carry the anticipated signs, the value of the coefficient of GDP is much smaller than that in the original model (i.e., in the absence of per capita GDP). The reason is obvious. Multicollinearity is likely to exist between the two explanatory variables, i.e., gross GDP and GDP per capita. Hence, it seems appropriate to drop this variable from further analyses.

\subsection{Augmented Gravity Model}

Next, we estimate the augmented gravity model for Pakistan. In addition to the traditional variables, the model incorporates the per capita differential and several other dummies to capture the impact of certain important factors on bilateral trade. The general model employed is shown as Equation (6) below:

$\log \left(\right.$ Trade $\left._{i t}\right)=\beta_{0}+\beta_{1} \log X_{1 i t}+\beta_{2} \log X_{2 i t}+\ldots .+\delta_{1} D_{1 t}+\delta_{2 t} D_{2 t}+\ldots \ldots+\omega_{i t}$ (6)

$X$ stands for quantitative/ordinary variables (product of GDP, distance, and GDP differential) and D for qualitative/binary variables (dummies). The results are presented in Table- 2 and a brief discussion follows. 
Table-2: Augmented Gravity Model

\begin{tabular}{lccc}
\hline Explanatory Variable & Coefficient & Std. Error* & t-Statistic $^{*}$ \\
\hline Constant & -0.92 & 6.02 & -0.15 \\
Product of GDP & 0.92 & 0.05 & 18.93 \\
Distance & -1.95 & 0.73 & -2.67 \\
Border & -1.51 & 0.65 & -2.33 \\
Language & 0.86 & 0.34 & 2.55 \\
SAARC & -0.19 & 0.49 & -0.39 \\
ECO & 0.52 & 0.56 & 0.92 \\
Per capita GDP differential & 0.11 & 0.05 & 2.32 \\
Adjusted R-squared & 0.50 & - & - \\
\hline
\end{tabular}

Note: *The standard errors and t-statistics are hetroskedasticity-robust (White, 1980).

As evident from the above, the coefficient of the product of GDP is statistically significant at 1 percent and carries the expected sign. This reveals that Pakistan's bilateral trade increases by 0.92 percent as the product of GDP increases by 1 percent. The coefficient of the distance variable is negative and statistically significant at 5 percent. It implies that a 1 percent increase in distance leads to 1.95 percent reduction in trade between Pakistan and its trading partners.

In addition to the two primary variables, we include the absolute difference in GDP per capita for a pair of countries as an explanatory variable in the model so as to test for the relative strength of the Linder hypothesis vis-à-vis the Heckscher-Ohlin (HO) hypothesis. The coefficient of the variable concerned is positive and significant at 5 percent. The estimated value is 0.11 , which implies that bilateral trade increases as the difference between the per capita GDP of Pakistan and its trading partner increases, but less than proportionately. Thus, the available results support the $\mathrm{HO}$ hypothesis (differences in factor endowments) in the case of Pakistan.

We discuss the impact of various qualitative variables below:

(i) To control for adjacency, we have included the border dummy variable. Interestingly, the coefficient of this variable has a negative sign (-1.51) and is statistically significant at 5 percent. As the model is specified in log form, we have to interpret the coefficient by taking the exponential. The projected results $[\exp (-1.508914)-1=-0.78]$ imply 
that Pakistan's trade with its neighboring countries (those that share a common border) is 78 percent lower than expected. Apparently the results contradict theory/common wisdom. However, the reasons are obvious: only two countries, India and Iran (included in the analysis), have a common border with Pakistan. Trade with India, in particular, is restricted due to political conflict. Further, much of the border trade between Pakistan and Iran and Pakistan and India is underground and unrecorded. Likewise, lower skills and similar products, the low level of industrialization in the region, and more or less the same level of technical progress and development are also why Pakistan's trade with its neighboring countries is not as high as one would expect theoretically.

(ii) The dummy for common language is statistically significant at 5 percent and has the expected positive sign. The coefficient value 1.35 [exp (0.856285)-1 =1.35] indicates that trade between Pakistan and those countries with whom it shares a common language or culture will be higher by 135 percent.

(iii) The SAARC dummy variable does not show any significant impact on Pakistan's trade. The coefficient of the SAARC dummy itself is 0.17 [exp (-0.19)-1 = -0.17]. It shows that Pakistan's trade with SAARC countries is 17 percent lower than that of the rest of the world. Mutual trade within the region as a share of total trade is lowest in South Asia. The trade-GDP ratio is decreasing within SAARC, but increasing among countries outside SAARC. As discussed above, the low level of trade within SAARC is mainly due to political disputes between the major players, Pakistan and India. Similarly, countries' low levels of industrialization, similar levels of development, and enormous volume of unrecorded trade might also contribute to poor results. India and Pakistan have a significant role to play in the success of SAARC. Both countries account for four-fifths (80 percent) of the regional economy. However, efforts to promote regional integration and cooperation through SAARC have suffered greatly due to tensions and conflicts in the region (World Bank, 2006).

(iv) Likewise, the model fails to establish a significant relationship between Pakistan and other ECO members. Hence, we can conclude that both regional organizations are not playing their expected role in boosting trade flows among member countries. In contrast, all SAARC and ECO countries are involved in high trade outside these nominal RTAs. 


\subsection{Further Augmentation}

Here, we try to re-estimate the model by incorporating certain other explanatory variables, particularly openness to trade and the real exchange rate, which seem to be important in international trade considerations. The inclusion of these variables will provide a test for the sensitivity of the model and its robustness. Two alternative proxies have been used by researchers for openness, namely the proportion of customs-to-total tax revenues and the trade-GDP ratio. However, the latter proxy is often preferred for obvious reasons. For instance, Rahman (2003) uses the trade-GDP ratio in a gravity model to analyze trade flows between Bangladesh and its trading partners. Hence, we also use this variable as a proxy for openness, primarily because data is available for the countries concerned.

The enhanced model shows some improvement over its counterpart in terms of goodness of fit. The coefficients for the primary variables, i.e., GDP (size of the economy) and distance between economic centers, are significant and carry the expected signs. Thus, the enhanced model supports the former results as per the basic gravity theory. It is interesting to note that all the dummies in the enhanced model carry the same signs as depicted in the original model. In particular, the common border variable stands again in contrast to what common wisdom would suggest. All the variables are statistically significant, with the exception of the ECO and SAARC dummies. The coefficient for the GDP differential is positive and significant, so our results support the $\mathrm{HO}$ hypothesis, as explained earlier. The real exchange rate is statistically significant at 1 percent, which implies that currency depreciation has a positive impact on Pakistan's trade. The results are depicted in Table-3. 
Table-3: Extended Augmentation

\begin{tabular}{lccc}
\hline Explanatory Variable & Coefficient & Std. Error & t-Statistic \\
\hline Constant & -0.88 & 6.29 & -0.14 \\
Product of GDP & 0.89 & 0.04 & 19.84 \\
Distance & -1.69 & 0.71 & -2.40 \\
Border & -1.10 & 0.52 & -2.12 \\
Language & 0.79 & 0.45 & 1.74 \\
SAARC & 0.28 & 0.54 & 0.51 \\
ECO & 1.00 & 0.73 & 1.36 \\
Per capita GDP differential & 0.13 & 0.04 & 3.06 \\
Real exchange rate & 0.04 & 0.02 & 2.33 \\
Trade openness (partner & 0.41 & 0.14 & 2.85 \\
country) & & & \\
Trade openness (Pakistan) & 1.45 & 0.29 & 4.93 \\
Adjusted R-squared & 0.53 & & \\
\hline
\end{tabular}

However, we are particularly interested in the impact of trade openness. We have estimated the model by including the variable concerned for Pakistan and its trading partners separately. The variable is significant at 5 percent and has the expected positive sign. This implies that Pakistan's trade with all partners under reference is likely to improve considerably with the liberalization of trade and removal of barriers in these countries. Specifically, only a 1 percent improvement in trade openness in its partner countries could increase Pakistan's trade by 0.41 percent. This is very important for the country's economy provided that its trading partners in the West open their doors to Pakistan's exports. Similarly, the coefficient of trade openness for Pakistan itself is also significant. It indicates that a 1 percent improvement in domestic openness could increase Pakistan's trade by as much as 1.45 percent. However, this result should be viewed with caution. In case Pakistan reduces trade barriers and opens its markets completely, as required by WTO, nothing but the volume of imports will increase, which could lead to further deterioration of the balance of trade. On the other hand, an improvement in the 'openness' of other countries is likely to increase Pakistan's exports significantly, despite tough competition in the markets. 


\subsection{Segmented Gravity Analysis}

In this section, we discuss the results of the gravity model when the countries concerned are segmented into different regional blocs, i.e., the EU, SAARC, ECO, ASEAN, NAFTA, and the countries of the Middle East, Far East, and Latin America. The objective is to compare these results with those obtained from the larger model, and gain deeper insight into the relative significance of these regional groups for Pakistan. For this purpose, we adopt a two-pronged strategy:

In the first approach, the total number of countries is now distributed into smaller groups through the cross-section and the time span remains unchanged, i.e., the regressions cover the years 1981-2005. However, only three variables are included this time in each case, namely the product of GDP, distance, and the trade-GDP ratio as a proxy for openness. All other dummies are excluded to avoid the identification problem. We report the results in consolidated form in Table-4 below.

Table-4: Gravity Models - Comparative Position

\begin{tabular}{lccccc}
\hline $\begin{array}{l}\text { Model } \downarrow \\
\text { Variable } \rightarrow\end{array}$ & Constant & $\begin{array}{c}\text { Product } \\
\text { of GDP }\end{array}$ & Distance & $\begin{array}{c}\text { Trade/GDP } \\
\text { (Partner) }\end{array}$ & $\begin{array}{c}\text { R-Square } \\
\text { adjusted }\end{array}$ \\
\hline Pak-versus-all & -0.88 & 0.89 & -1.69 & 0.41 & 0.53 \\
countries & $(6.29)$ & $(0.04)$ & $(0.71)$ & $(0.14)$ & \\
Pak-versus-EU & -25.21 & 0.97 & -0.82 & -0.54 & 0.68 \\
& $(7.58)$ & $(0.06)$ & $(1.00)$ & $(0.17)$ & \\
Pak-versus- & -2.45 & 0.65 & -0.81 & 1.31 & 0.51 \\
ASEAN & $(2.40)$ & $(0.06)$ & $(0.24)$ & $(0.16)$ & \\
Pak-versus- & -10.85 & 0.61 & -0.35 & 0.25 & 0.54 \\
SAARC-ECO & $(5.92)$ & $(0.13)$ & $(0.44)$ & $(0.33)$ & \\
Pak-versus- & 49.98 & 0.92 & -7.99 & 1.03 & 0.39 \\
Middle East & $(11.84)$ & $(0.07)$ & $(1.48)$ & $(0.51)$ & \\
Pak-versus-Far & -3.07 & 0.66 & -0.77 & 0.17 & 0.72 \\
East & $(2.69)$ & $(0.06)$ & $(0.19)$ & $(0.12)$ & \\
Pak-versus- & -53.6 & 1.65 & -1.93 & 0.16 & 0.61 \\
NAFTA-Lt. Am. & $(36.0)$ & $(0.17)$ & $(3.72)$ & $(0.30)$ & \\
\hline
\end{tabular}

Note: The standard errors are given in parentheses and these are hetroskedasticity-robust (White, 1980).

The coefficients of the 'size' variable (product of GDP) are of the same order except in the case of NAFTA. Here, the coefficient is quite large, obviously due to the presence of a very large economy (the US). 
The coefficients for distance are of varying magnitude and significance level. Although the signs are as expected, the values are insignificant in many cases. This means that, although greater distance reflects higher transportation costs, other factors responsible for higher trade can easily overcome the distance factor.

The coefficients for trade openness show some interesting trends. With the exception of EU countries, all values are positive, thereby indicating that there is potential for Pakistan to expand its trade, provided that the countries concerned become more open or Pakistan enters into some sort of agreement with these groups/countries. The EU bloc is considerably open to international trade and Pakistan will face tough competition in the European market in the times to come, since our exports are mostly textiles, leather, and garments.

We have included four ASEAN countries in the analysis: Indonesia, Malaysia, the Philippines, and Thailand. Pakistan's trade with ASEAN is likely to improve significantly with the liberalization of trade and removal of barriers in these countries. The coefficient for trade openness is indicative of these prospects, i.e., a 1 percent increase in trade openness in ASEAN countries results in a 1.31 percent increase in Pakistan's trade. This is an important signal for Pakistan and it should explore the new avenues available in these countries.

We have combined the members of SAARC and ECO for datarelated reasons. The group includes India, Bangladesh, Sri Lanka, Iran, and Turkey, besides Pakistan. The coefficient for the size of economies is statistically significant and carries the expected sign. In contrast, the coefficient for the distance variable is insignificant, although it carries the expected sign. The reasons for its insignificance can be easily explained keeping in view other factors that affect trade. Likewise, the coefficient of trade openness is not statistically significant, although the sign is positive. Pakistan is a founder member of both organizations. Unfortunately, for obvious reasons, ${ }^{2}$ no significant progress has been made so far to transform these entities into functioning free trade unions.

\footnotetext{
${ }^{2}$ Some commentators refer to the intra-block trade diverting effects if a country enters into some sort of trade agreement with others. In fact, Pakistan has inherent trade agreements with other members of ECO and SAARC. However, the volume of our trade is very small with members of these groups. Thus, the intra-block trade diverting effects will be negligible, if any.
} 
The countries in the Middle East are major trading partners of Pakistan and we have included Saudi Arabia, Kuwait, Egypt, Morocco, Kenya, and Nigeria (six countries). The results indicate that all the coefficients are statistically significant and have the expected signs.

Another important region is the Far East, which includes trading partners such as China, Japan, Korea, Hong Kong, Australia, and New Zealand. The results depict the expected signs for all coefficients. The coefficient for product of GDP is significant. Likewise, the coefficient for distance is statistically significant at 1 percent and indicates that trade between Pakistan and Far East countries increases by 0.77 percent if distance or transportation cost is reduced by 1 percent. The expansion and further improvement of the Karakoram Highway is likely to reduce transportation costs between China and Pakistan.

The last group in our segmented analysis comprises three countries from NAFTA (Canada, the US, and Mexico) and three from Latin America (Argentina, Brazil, and Chile). The countries are merged together for data-related reasons and to facilitate estimation. However, the results are not very encouraging. Both the coefficients for distance and trade openness are statistically insignificant. The reason is clear: Pakistan's trade with all these countries, particularly in Latin American, is not up to the mark. The only exception is the US, in which case the dependence of Pakistan is very high. The large size of the US economy obscures all other variables.

The second approach would be to introduce block-specific dummies and treat the data as a whole as suggested by the anonymous referees. However, the revised regression results do not show any significant improvements over the segregated regressions. The results do compare with the overall augmented model, however, and are shown in Appendix-III as a token of information only.

\section{Trade Potential of Pakistan}

We are now ready to evaluate Pakistan's trade potential. As discussed above, the results obtained from the gravity models are fairly reliable, keeping in view the data limitations and problems arising from the quantum of underground trade across territorial borders. 


\subsection{Concept and Methodology}

The concept of trade potential has been extensively used by researchers studying international trade relations, particularly among eastern European countries. The methodology consists of selecting a sample of countries for which trade is supposed to have reached its potential. A gravity equation is then estimated to explain bilateral trade within the sample. The estimated coefficients given by the equation are used in simulations to predict the volume of trade between any pair of countries, given that data on GDP, distance, and population, etc. are systematically available. The simulated or predicted value of bilateral trade is then compared with the observed values to infer bilateral trade potential. As noted by Helmers et al. (2005), this methodology can be applied either at the aggregate or industry level. In the present study, we will carry out our analysis at the aggregate level.

We have estimated the augmented gravity model for Pakistan vis-àvis 41 countries for a fairly long period (1981-2005). We will use the ratio $(\mathrm{P} / \mathrm{A})$ of predicted trade $(\mathrm{P})$-arrived at by the estimated value of the dependent variable-to actual trade (A) of Pakistan with the partner concerned to evaluate their trade potential, and to forecast the future trade direction. If the value of $\mathrm{P} / \mathrm{A}$ exceeds unity, this implies that Pakistan has the potential to expand trade with the respective country. Similarly, the absolute difference between the potential and actual level of trade (P-A) can equally be used for this purpose. A positive value implies the possibility of trade expansion in the future while a negative value shows that Pakistan has exceeded its trade potential with a particular country. By using either the ratio or the difference indicators, we can classify those countries with which Pakistan has potential for the expansion of trade or otherwise.

\subsection{Evaluation of Trade Potential}

As noted above, we use the coefficients' estimates to evaluate trade potential, both from the overall (general-augmented) as well as the regional (segregated) models. Finally, we have to compare the results of both sets of estimates. For the sake of simplicity, we divide the entire time span (1981-2005) into five sub-periods to calculate the average values of predicted $(\mathrm{P})$ and actual trade $(\mathrm{A})$. The trade potential results, based on the coefficients of the aggregate model (see Table-3), are reported in detail in Appendix-IV (Tables I-II). Here, we discuss the results for the most recent period 2001-05 (Table-5). 
According to our estimation, Pakistan possess sufficient potential (on average) to expand its trade with Australia, Austria, Bangladesh, Canada, China, Germany, Denmark, Spain, France, the UK, Japan, Hong Kong, Italy, Iran, Korea, Kuwait, Sri Lanka, Malaysia, New Zealand, the Philippines, Sweden, and Switzerland. However, the maximum trade potential exists with Norway and Brazil since the $(\mathrm{P} / \mathrm{A})$ ratio is considerably high. The $(\mathrm{P} / \mathrm{A})$ ratio equals unity (or nearly so) in the case of the Netherlands and Thailand, which implies that Pakistan's actual trade with these countries has reached its potential level. In contrast, Pakistan's actual trade has exceeded the predicted level for many countries $(\mathrm{P} / \mathrm{A}<1)$, for instance, with Chile and Mexico.

Table-5: Overall Trade Potential of Pakistan (Summary)

\begin{tabular}{lclc}
\hline $\begin{array}{l}\text { Indicator } \\
\text { Country }\end{array}$ & $\begin{array}{c}\text { P/A } \\
\text { 2001-2005 }\end{array}$ & $\begin{array}{l}\text { Indicator } \\
\text { Country }\end{array}$ & $\begin{array}{c}\text { P/A } \\
\text { 2001-2005 }\end{array}$ \\
\hline Australia & 1.02 & Italy & 1.05 \\
Austria & 1.04 & Japan & 1.09 \\
Bangladesh & 1.06 & Korea & 1.06 \\
Brazil* & 1.13 & Kuwait & 1.03 \\
Canada & 1.02 & Sri Lanka & 1.09 \\
China & 1.04 & Malaysia & 1.08 \\
Germany & 1.04 & Netherlands & 1.00 \\
Denmark & 1.06 & Norway* & 1.14 \\
Spain & 1.02 & New Zealand & 1.06 \\
France & 1.06 & Philippines & 1.06 \\
UK & 1.02 & Sweden & 1.08 \\
Hong Kong & 1.02 & Switzerland & 1.03 \\
Iran & 1.06 & Thailand & 1.01 \\
Argentina & 0.989 & Morocco & 0.761 \\
Belgium & 0.973 & Mexico** & 0.699 \\
Chile** & 0.701 & Nigeria & 0.712 \\
Egypt & 0.787 & Portugal & 0.989 \\
Greece & 0.965 & Saudi Arabia & 0.960 \\
Indonesia & 0.959 & Turkey & 0.958 \\
India & 0.949 & USA & 0.987 \\
Kenya & 0.991 & & \\
\hline
\end{tabular}

Note: * Indicates high trade potential.

** Indicates exhausted trade potential. 
We have also used the results of the segmented gravity models to evaluate the trade potential of Pakistan across different geographic regions. It can be recalled that we included only three quantitative variables in the analysis and excluded all dummies. Even then, the results of the two specifications are comparable (see Table-4). The detailed results are shown in Tables III-IV in Appendix-IV, and the summary for the period 2001-05 is shown below in Table-6.

A quick look at the table reveals that there is significant scope for Pakistan to expand its trade with a number of countries. The maximum potential for 2001-2005 exists the Asia-Pacific region, followed by Western Europe, the Middle East, and Latin America. In the Asia-Pacific region, Pakistan has significant trade potential with Japan, Sri Lanka, Bangladesh, Malaysia, the Philippines, and New Zealand, while in the EU bloc, the potential for expanding trade exists with Norway, Italy, France, Sweden, and Denmark. In the Middle East, Pakistan has significant potential for the expansion of trade only with Iran, and within the Latin American region, there is high trade potential with Mexico. At present, Pakistan has approached the maximum trade levels with NAFTA countries; in other words, the potential is already exhausted. However, some scope exists there for future trade expansion with Canada. 
Table-6: Regional Trade Potential of Pakistan (Summary)

\begin{tabular}{|c|c|c|c|}
\hline $\begin{array}{l}\text { Indicator } \\
\text { Country }\end{array}$ & $\begin{array}{c}\text { P/A } \\
2001-2005 \\
\end{array}$ & $\begin{array}{l}\text { Indicator } \\
\text { Country }\end{array}$ & $\begin{array}{c}\text { P/A } \\
2001-2005 \\
\end{array}$ \\
\hline \multicolumn{4}{|c|}{ EU } \\
\hline Austria & 1.054 & Belgium & 0.753 \\
\hline Germany & 1.139 & Spain & 0.952 \\
\hline Denmark & 1.129 & Greece & 0.825 \\
\hline France & 1.280 & Netherlands & 0.889 \\
\hline UK & 1.024 & & \\
\hline Italy & 1.350 & & \\
\hline Norway & 1.508 & & \\
\hline Portugal & 1.043 & & \\
\hline Sweden & 1.319 & & \\
\hline Switzerland & 1.135 & & \\
\hline \multicolumn{4}{|c|}{ SAARC and ECO } \\
\hline Bangladesh & 1.343 & India & 0.689 \\
\hline Sri Lanka & 2.900 & Iran & 0.490 \\
\hline & & Turkey & 0.666 \\
\hline \multicolumn{4}{|c|}{ ASEAN } \\
\hline Malaysia & 1.018 & Indonesia & 0.377 \\
\hline Philippines & 5.155 & & \\
\hline Thailand & 1.509 & & \\
\hline \multicolumn{4}{|c|}{ Far East } \\
\hline Japan & 1.618 & Australia & 0.909 \\
\hline Korea & 1.082 & China & 0.942 \\
\hline New Zealand & 1.075 & Hong Kong & 0.893 \\
\hline \multicolumn{4}{|c|}{ Middle East and ECO } \\
\hline Iran & 1.715 & Egypt & 0.486 \\
\hline Kuwait & 1.308 & Saudi Arabia & 0.886 \\
\hline & & Turkey & 0.885 \\
\hline \multicolumn{4}{|c|}{ Middle East and Africa } \\
\hline \multirow[t]{5}{*}{ Kuwait } & 1.469 & Saudi Arabia & 0.526 \\
\hline & & Egypt & 0.248 \\
\hline & & Morocco & 0.270 \\
\hline & & Kenya & 0.900 \\
\hline & & Nigeria & 0.414 \\
\hline \multicolumn{4}{|c|}{ NAFTA and Latin America } \\
\hline USA & 1.629 & Chile & 0.652 \\
\hline Argentina & 1.397 & Mexico & 0.508 \\
\hline Brazil & 3.964 & & \\
\hline Canada & 1.889 & & \\
\hline
\end{tabular}

Note: $\mathrm{P} / \mathrm{A}>1$ indicates high trade potential, otherwise exhausted potential. 


\section{Conclusions and Policy Implications}

All models and estimation techniques developed over time suffer from weaknesses. The present study is empirically based and therefore relies heavily on the availability, completeness, and authenticity of the data. The gravity model of trade also has its strengths as well as limitations. It is natural that trade relations between different countries should be stronger if they are comparatively nearer, have common borders, a common language, and close social relations. Political affairs (conflicts/tensions or friendships/coordination) are sometimes more powerful than economic and commercial considerations.

Our estimations reveal that Pakistan has the highest trade potential with partners in the Asia-Pacific region (ASEAN) followed by Western Europe, the Middle East, Latin America, and North America for 2001-2005. The maximum trade potential exists for Japan, Sri Lanka, Bangladesh, Malaysia, the Philippines, New Zealand, Norway, Italy, Sweden, and Denmark. Therefore, Pakistan should explore ways and means to enhance its trade relationships with these regions/countries. In any case, Pakistan will have to improve the quality of its exports and minimize the cost of production to enable it to compete well in the international market.

Our results illustrate the fact that Pakistan's trade within SAARC is very low, particularly with India. However, this result should be interpreted with caution, taking into consideration the volume of underground trade. There has been some recent improvement, as indicated by estimates for the period 2001-2005, i.e., the actual trade of Pakistan with India has slightly surpassed the predicted level. However, our trade with India is still low compared to others. Despite the fact that India has granted most favored nation (MFN) status to Pakistan, the latter is not in a position to export significantly to India. The reasons are both economic and political. Tensions between the two countries persist, which could continue to hamper even future trade prospects. Further, both countries are more or less in the same phase of development, have similar products and productive skills, and hence would not fulfill each other's needs even if trade barriers were removed. Of course, this does not imply that there are no prospects of future trade expansion between the two countries, but this will be conditional on some sort of political advancement to remove the roots of conflict. Although the launch of SAFTA in 2006 has resulted in significant changes in custom tariffs and reduced trade-related barriers, there is still room for further trade liberalization in the region. 

below.

The implications of this study for policy purposes are enumerated

(i) Trade barriers need to be reduced. However, this depends on the behavior of trading partners toward Pakistan, particularly in the West, who most often impose restrictions on Pakistani products.

(ii) One of the main problems in South Asian trade is the inadequacy of the region's transport and infrastructure network. Improvements in infrastructure are a prerequisite for successful trade flows within South Asia.

(iii) The propensity of all partners to export and import must be taken into account adequately when a trade policy is set, since Pakistan's trade is not sufficiently independent of country-specific effects.

(iv) So far, regional economic groupings, particularly SAARC and ECO, have failed to show any significant impacts on bilateral trade. Regional trade is constrained by restrictive rules and regulations, extensive sensitive lists, and uncoordinated efforts, besides the existing political tensions between India and Pakistan, both of who are major players. All these factors currently threaten to limit the trade potential of Pakistan within South Asia. Addressing these problems will depend on the extent to which South Asian Countries are willing to adopt new approaches.

(v) Special attention is required to improve the quality of exports so as to gain ground in competitive world markets though quality control and cost efficiency are necessary, not sufficient, conditions for trade promotion. Extensive efforts are needed on economic as well as political, diplomatic, and social fronts to retain existing markets and explore new ones. In particular, Pakistan ought to focus on ASEAN and the Middle East, where sufficient scope for trade exists. 


\section{Appendix-I}

\section{Direction of Trade (Pakistan)}

Major Export Markets

(Percentage Share)

\begin{tabular}{lcccccccccc}
\hline Country & $\mathbf{9 8 - 9 9}$ & $\mathbf{9 9 - 0 0}$ & $\mathbf{0 0 - 0 1}$ & $\mathbf{0 1 - 0 2}$ & $\mathbf{0 2 - 0 3}$ & $\mathbf{0 3 - 0 4}$ & $\mathbf{0 4 - 0 5}$ & $\mathbf{0 5 - 0 6}$ & $\mathbf{0 6 - 0 7}$ & $\mathbf{0 7 - 0 8}$ \\
\hline USA & 21.8 & 24.8 & 24.4 & 24.7 & 23.5 & 23.9 & 23.9 & 25.5 & 24.6 & 19.5 \\
Germany & 6.6 & 6.0 & 5.3 & 4.9 & 5.2 & 4.9 & 4.8 & 4.2 & 4.1 & 4.3 \\
Japan & 3.5 & 3.1 & 2.1 & 1.8 & 1.3 & 1.1 & 1.1 & 0.8 & 0.7 & 0.7 \\
UK & 6.6 & 6.8 & 6.3 & 7.2 & 7.1 & 7.6 & 6.2 & 5.4 & 5.6 & 5.4 \\
Hong Kong & 7.1 & 6.1 & 5.5 & 4.8 & 4.6 & 4.7 & 3.9 & 4.1 & 3.9 & 2.7 \\
Dubai & 5.4 & 5.7 & 5.3 & 7.9 & 9.0 & 7.3 & 3.3 & 5.6 & 1.1 & 0 \\
Saudi Arabia & 2.4 & 2.5 & 2.9 & 3.6 & 4.3 & 2.8 & 2.5 & 2.0 & 1.7 & 2.0 \\
\hline Subtotal & $\mathbf{5 3 . 4}$ & $\mathbf{5 5 . 0}$ & $\mathbf{5 1 . 8}$ & $\mathbf{5 4 . 9}$ & $\mathbf{5 5 . 0}$ & $\mathbf{5 2 . 3}$ & $\mathbf{4 5 . 7}$ & $\mathbf{4 7 . 6}$ & $\mathbf{4 8 . 1}$ & $\mathbf{3 4 . 6}$ \\
\hline Other & 46.6 & 45.0 & 48.2 & 45.1 & 45.0 & 47.7 & 54.3 & 52.4 & 51.9 & 65.4 \\
countries & & & & & & & & & & \\
\hline Total Exports & $\mathbf{1 0 0 . 0}$ & $\mathbf{1 0 0 . 0}$ & $\mathbf{1 0 0 . 0}$ & $\mathbf{1 0 0 . 0}$ & $\mathbf{1 0 0 . 0}$ & $\mathbf{1 0 0 . 0}$ & $\mathbf{1 0 0 . 0}$ & $\mathbf{1 0 0 . 0}$ & $\mathbf{1 0 0 . 0}$ & $\mathbf{1 0 0 . 0}$ \\
\hline
\end{tabular}

Source: Ministry of Commerce, Government of Pakistan: Economic Survey 2006-07.

Major Import Markets

(Percentage Share)

\begin{tabular}{lcccccccccc}
\hline Country & $\mathbf{9 8 - 9 9}$ & $\mathbf{9 9 - 0 0}$ & $\mathbf{0 0 - 0 1}$ & $\mathbf{0 1 - 0 2}$ & $\mathbf{0 2 - 0 3}$ & $\mathbf{0 3 - 0 4}$ & $\mathbf{0 4 - 0 5}$ & $\mathbf{0 5 - 0 6}$ & $\mathbf{0 6 - 0 7}$ & $\mathbf{0 7 - 0 8}$ \\
\hline USA & 7.7 & 6.3 & 5.3 & 6.7 & 6.0 & 8.5 & 7.6 & 5.8 & 8.1 & 6.1 \\
Japan & 8.3 & 6.3 & 5.3 & 5.0 & 6.6 & 6.0 & 7.0 & 5.6 & 5.7 & 4.6 \\
Kuwait & 5.9 & 12.0 & 8.9 & 7.1 & 6.6 & 6.4 & 4.6 & 6.2 & 5.4 & 7.5 \\
Saudi Arabia & 6.8 & 9.0 & 11.7 & 11.6 & 10.7 & 11.4 & 12.0 & 11.2 & 11.5 & 13.4 \\
Germany & 4.1 & 4.1 & 3.5 & 4.3 & 4.6 & 3.9 & 4.4 & 4.7 & 4.1 & 3.2 \\
UK & 4.3 & 3.4 & 3.2 & 3.4 & 2.9 & 2.8 & 2.6 & 2.8 & 2.3 & 1.9 \\
Malaysia & 6.7 & 4.3 & 3.9 & 4.4 & 4.6 & 3.9 & 2.6 & 3.0 & 3.0 & 3.9 \\
Subtotal & 43.8 & 45.4 & 41.8 & 42.5 & 42.0 & 42.9 & 40.8 & 39.3 & 40.1 & 40.6 \\
Other & 56.2 & 54.6 & 58.2 & 57.5 & 58.0 & 57.1 & 59.2 & 60.7 & 59.9 & 59.4 \\
countries & & & & & & & & & & \\
\hline Total Imports & $\mathbf{1 0 0 . 0}$ & $\mathbf{1 0 0 . 0}$ & $\mathbf{1 0 0 . 0}$ & $\mathbf{1 0 0 . 0}$ & $\mathbf{1 0 0 . 0}$ & $\mathbf{1 0 0 . 0}$ & $\mathbf{1 0 0 . 0}$ & $\mathbf{1 0 0 . 0}$ & $\mathbf{1 0 0 . 0}$ & $\mathbf{1 0 0 . 0}$
\end{tabular}

Source: Ministry of Commerce, Government of Pakistan: Economic Survey 2006-07. 


\section{Appendix-II}

\section{Definition of Variables Used in Model}

i. Trade

Trade in goods and services, between two countries, is the dependent variable. It is the sum of exports and imports between the two partners (in value terms).

ii. Gross Domestic Product (GDP)

GDP and population are two standard proxies used to measure the size of an economy. GDP is positively related to trade: the higher the GDP, the higher the trade. In most of the gravity models used here, the product of the GDPs of two countries has been used as a proxy for economic/market size and the productive capacities of the two countries. A positive sign is expected between trade and GDP. The population of the countries concerned is sometimes used as a proxy for market size.

iii. Per Capita GDP (PCGDP)

This variable is precisely equivalent, whether we express the explanatory variables as either GDP and population separately or as GDP per capita to account for two in one. Most often, GDP per capita has been used in gravity model estimation since it is also a good proxy for level of development. GDP per capita describes the link between the level of trade and a country's stage of development. The more developed two countries are, the more likely is the level of trade between them. Therefore, a positive sign is expected between trade and per capita GDP. We have included this variable only in the preliminary test.

iv. Per Capita GDP Differential - Absolute (PCGDPD)

According to the prediction of the standard gravity model, countries with similar levels of GDP per capita will trade more than 
countries with dissimilar levels. Therefore, the absolute differential in the per capita GDPs of trading partners has been used as an argument. ${ }^{3}$

Our objective is not to test the validity of different theories per se, since our focus is on trade potential. However, we include this variable to determine the byproduct of our analysis in terms of the two contrasting hypotheses. A negative sign on the coefficient will support the Linder hypothesis, while a positive sign will support the $\mathrm{HO}$ hypothesis.

\section{v. Distance}

Distance is a proxy for transportation cost. The distance between two trading countries is often measured using the great circle formula (Head, 2000), which takes into account the longitude and latitude of the capital or "economic centre" of each country. Greater distances not only indicate larger transportation costs, but are also correlated with larger cultural differences, which can retard the transfer of information and establishment of trust. Therefore, we expect a negative sign in the gravity equation for the distance variable.

As already pointed out, researchers often incorporate a number of dummies in the model to capture the impact of certain qualitative variables, geographical factors, and historical ties between countries. A brief explanation of these variables follows below.

\section{vi. Common Border/Adjacency}

Two countries adjacent to each other or sharing a common border are more likely to trade due to stronger social and economic relations at the public level. To capture this feature, a dummy is often included in the

3 The inclusion of this variable in the model is to verify and provide support to the contrasting opinions on this issue in the trade theory. For instance, the Helpman-Krugman theory predicts that the volume of trade should increase with increasingly equal distribution of national income (Batra: 2006). The Hecksher-Ohlin theory however, stands in stark contrast to this opinion and holds that countries with dissimilar levels of output will trade more than countries with similar levels. According to the Linder hypothesis, countries with similar levels of per capita income will have similar preferences and similar but differentiated products; and therefore they should trade more with each other. This hypothesis is often viewed as similar to the Helpman-Krugman theory in its prediction. "The Hecksher-Ohlin theory on the other hand predicts that the sum of logs of income per capita of both countries will have a positive effect on the log of trade, while the Linder hypothesis is associated with the prediction that the absolute value of the difference between per capita incomes will have a negative effect on trade. A positive value falls in the category of H-O theory” (Batra: 2006). 
gravity model, in addition to the primary variable of center-to-center physical distance. It accounts for the effective distance between neighboring countries that are likely to be engaged in mutual trade more frequently (Head, 2000). The coefficient of the border dummy is expected to be positively related to trade.

vii. Common Language

People of two countries who speak a common language (and share a common culture and traditions) are likely to trade more highly than those who do not share these characteristics. A common medium of communication is expected to reduce transaction costs as it helps facilitate trade negotiations (Batra, 2006). The dummy for a common language is therefore expected to have a positive sign.

viii. RTAs

In order to facilitate international trade, countries often enter into bilateral and regional trading agreements. These arrangements have shown a positive effect on the volume of trade. To capture the impact of such contracts, one or more dummy variables are often added to the model, taking a symbolic value of unity if both countries belong to the same economic/trading community, and zero otherwise. The estimated coefficient describes the weight that can be attributed to a special regional effect. Many studies have found that trade between partner countries has been enhanced threefold if they are members of the same RTA. The inclusion of this dummy also helps analyze the trade diversion and trade creation effect. As noted above, we have included two dummies for RTAs, i.e., SAARC and ECO.

ix. Trade Openness

The more open a country, the greater its involvement in trade. The proportion of customs-to-total tax revenues or the trade-GDP ratio can be used as proxies for openness. We expect a positive sign for this variable.

x. Real Exchange Rate

In some studies, the real exchange rate is used as an explanatory variable and a proxy for prices. It is computed as local currency per unit of foreign currency adjusted for domestic and foreign inflation. Sometimes, the exchange rate adjusted for purchasing power parity is used. 
Appendix-III

Augmented Gravity Model with Bloc-Specific Dummies

\begin{tabular}{|c|c|c|c|c|c|c|c|c|c|c|}
\hline $\begin{array}{l}\text { Model } \\
\text { Variables } \\
\end{array}$ & Constant & $\begin{array}{c}\text { Product of } \\
\text { GDP } \\
\end{array}$ & Distance & DumBorder & DumBlock & DumLang & $\begin{array}{c}\text { Percapita } \\
\text { GDPD }\end{array}$ & RER & $\begin{array}{c}\text { Tradeopen } \\
\text { (Partner) }\end{array}$ & $\begin{array}{l}\text { R-Square } \\
\text { (Adjusted) }\end{array}$ \\
\hline $\begin{array}{l}\text { Pak-versus-all } \\
\text { countries }\end{array}$ & $\begin{array}{l}-0.88 \\
-6.29\end{array}$ & $\begin{array}{c}0.89 \\
-0.04\end{array}$ & $\begin{array}{l}-1.69 \\
-0.71\end{array}$ & $\begin{array}{l}-1.1 \\
0.52\end{array}$ & & $\begin{array}{l}0.79 \\
0.45\end{array}$ & $\begin{array}{l}0.13 \\
0.04\end{array}$ & $\begin{array}{l}0.04 \\
0.02\end{array}$ & $\begin{array}{c}0.41 \\
-0.14\end{array}$ & 0.53 \\
\hline Pak-versus-EU & $\begin{array}{l}0.71 \\
5.02\end{array}$ & $\begin{array}{l}0.86 \\
0.04\end{array}$ & $\begin{array}{c}-1.81 \\
0.57\end{array}$ & $\begin{array}{l}-0.83 \\
0.49\end{array}$ & $\begin{array}{l}-0.36 \\
0.5\end{array}$ & $\begin{array}{l}0.67 \\
0.42\end{array}$ & $\begin{array}{l}0.17 \\
0.04\end{array}$ & $\begin{array}{l}0.04 \\
0.01\end{array}$ & $\begin{array}{l}0.44 \\
0.13\end{array}$ & 0.53 \\
\hline $\begin{array}{l}\text { Pak-versus- } \\
\text { ASEAN }\end{array}$ & $\begin{array}{c}-0.45 \\
5.04\end{array}$ & $\begin{array}{l}0.87 \\
0.04\end{array}$ & $\begin{array}{l}-1.72 \\
0.56\end{array}$ & $\begin{array}{c}-0.52 \\
0.51\end{array}$ & $\begin{array}{l}0.92 \\
0.51\end{array}$ & $\begin{array}{c}0.77 \\
0.4\end{array}$ & $\begin{array}{l}0.17 \\
0.04\end{array}$ & $\begin{array}{l}0.04 \\
0.02\end{array}$ & $\begin{array}{l}0.42 \\
0.14\end{array}$ & 0.53 \\
\hline $\begin{array}{l}\text { Pak-versus- } \\
\text { SAARC-ECO }\end{array}$ & $\begin{array}{l}-1.24 \\
5.65\end{array}$ & $\begin{array}{l}0.87 \\
0.04\end{array}$ & $\begin{array}{c}-1.62 \\
0.63\end{array}$ & $\begin{array}{c}-0.89 \\
0.48\end{array}$ & $\begin{array}{l}0.63 \\
0.43\end{array}$ & $\begin{array}{l}0.78 \\
0.41\end{array}$ & $\begin{array}{l}0.16 \\
0.04\end{array}$ & $\begin{array}{l}0.04 \\
0.02\end{array}$ & $\begin{array}{l}0.43 \\
0.14\end{array}$ & 0.53 \\
\hline $\begin{array}{l}\text { Pak-versus- } \\
\text { Middle East }\end{array}$ & $\begin{array}{l}2.88 \\
7.28\end{array}$ & $\begin{array}{l}0.89 \\
0.04\end{array}$ & $\begin{array}{l}-2.09 \\
0.79\end{array}$ & $\begin{array}{l}-1.47 \\
0.85\end{array}$ & $\begin{array}{l}-1.7 \\
1.37\end{array}$ & $\begin{array}{l}-0.97 \\
0.42\end{array}$ & $\begin{array}{l}0.13 \\
0.03\end{array}$ & $\begin{array}{l}0.04 \\
0.02\end{array}$ & $\begin{array}{l}0.41 \\
0.14\end{array}$ & 0.54 \\
\hline $\begin{array}{l}\text { Pak-versus-Far } \\
\text { East }\end{array}$ & $\begin{array}{l}1.21 \\
5.97\end{array}$ & $\begin{array}{l}0.87 \\
0.04\end{array}$ & $\begin{array}{c}-1.91 \\
0.67\end{array}$ & $\begin{array}{l}-1.06 \\
0.64\end{array}$ & $\begin{array}{l}0.88 \\
0.72\end{array}$ & $\begin{array}{l}0.63 \\
0.43\end{array}$ & $\begin{array}{l}0.15 \\
0.04\end{array}$ & $\begin{array}{l}0.04 \\
0.02\end{array}$ & $\begin{array}{l}0.42 \\
0.14\end{array}$ & 0.53 \\
\hline $\begin{array}{l}\text { Pak-versus- } \\
\text { NAFTA-Lt. Am. }\end{array}$ & $\begin{array}{c}-0.43 \\
5.31\end{array}$ & $\begin{array}{l}0.87 \\
0.04\end{array}$ & $\begin{array}{c}-1.72 \\
0.59\end{array}$ & $\begin{array}{l}-0.7 \\
0.57\end{array}$ & $\begin{array}{c}-0.47 \\
0.77\end{array}$ & $\begin{array}{l}0.85 \\
0.44\end{array}$ & $\begin{array}{l}0.16 \\
0.04\end{array}$ & $\begin{array}{l}0.04 \\
0.02\end{array}$ & $\begin{array}{l}0.42 \\
0.14\end{array}$ & 0.53 \\
\hline
\end{tabular}




\section{Appendix-IV}

\section{Trade Potential of Pakistan (Overall)}

Table I: Countries with who Pakistan has Potential to Expand Trade

\begin{tabular}{|c|c|c|c|c|c|}
\hline $\begin{array}{l}\text { Indicator } \\
\text { Country }\end{array}$ & $\begin{array}{c}\text { P/A } \\
\text { 1981-1985 }\end{array}$ & $\begin{array}{c}\text { P/A } \\
1986-1990 \\
\end{array}$ & $\begin{array}{c}\text { P/A } \\
\text { 1991-1995 }\end{array}$ & $\begin{array}{c}\text { P/A } \\
1996-2000 \\
\end{array}$ & $\begin{array}{c}\text { P/A } \\
\text { 2001-2005 } \\
\end{array}$ \\
\hline Australia & 0.987807 & 1.006984 & 1.002350 & 0.976296 & 1.019392 \\
\hline Austria & 1.020216 & 0.913717 & 0.928857 & 1.113564 & 1.043261 \\
\hline Bangladesh & 0 & 0.904346 & 0.964926 & 1.055630 & 1.063008 \\
\hline Brazil & 0.704448 & 0.955113 & 0.942580 & 1.055182 & 1.135071 \\
\hline Canada & 0.963942 & 1.004363 & 0.988498 & 1.020242 & 1.017025 \\
\hline China & 0 & 0.968496 & 0.991877 & 1.030409 & 1.042315 \\
\hline Germany & 0.982393 & 0.970114 & 0.975568 & 1.024253 & 1.043572 \\
\hline Denmark & 1.000686 & 0.971761 & 0.947643 & 1.020916 & 1.061137 \\
\hline Spain & 0.996741 & 0.972349 & 0.993170 & 1.010794 & 1.020093 \\
\hline France & 1.007440 & 0.979509 & 0.941483 & 1.017949 & 1.056386 \\
\hline Hong Kong & 1.009422 & 1.047872 & 0.968451 & 0.961235 & 1.025583 \\
\hline Iran & 0.864536 & 0.947372 & 1.027135 & 1.088937 & 1.063372 \\
\hline Italy & 0.964299 & 0.959695 & 0.975110 & 1.041652 & 1.050654 \\
\hline Japan & 0.935945 & 0.951772 & 0.973588 & 1.048072 & 1.090864 \\
\hline Korea & 0.983764 & 0.958836 & 0.963877 & 1.019454 & 1.059754 \\
\hline Kuwait & 0.918818 & 0.989479 & 1.123642 & 1.013630 & 1.031012 \\
\hline Sri Lanka & 0.896914 & 0.902143 & 1.016087 & 1.052375 & 1.097329 \\
\hline Malaysia & 0.890703 & 0.990856 & 0.975157 & 1.033744 & 1.078544 \\
\hline Netherlands & 1.040937 & 0.990802 & 0.983002 & 0.994745 & 1.001742 \\
\hline Norway & 0.919394 & 0.868431 & 0.992859 & 1.078576 & 1.143315 \\
\hline New Zealand & 0.948895 & 0.930460 & 0.997818 & 1.032990 & 1.065682 \\
\hline Philippines & 1.159868 & 0.858587 & 0.959451 & 1.024688 & 1.063852 \\
\hline Sweden & 0.969832 & 0.960548 & 0.951934 & 1.037285 & 1.076830 \\
\hline Switzerland & 1.022602 & 0.999433 & 0.989270 & 0.958783 & 1.032698 \\
\hline Thailand & 1.032784 & 0.870258 & 1.054206 & 1.037856 & 1.008648 \\
\hline UK & 0.963554 & 0.994847 & 0.992713 & 1.020753 & 1.024415 \\
\hline
\end{tabular}

$\mathrm{P}=$ predicted trade, $\mathrm{A}=$ actual trade. 
Table II: Countries with who Pakistan has Exceeded Trade Potential

\begin{tabular}{lccccc}
\hline Indicator & P/A & P/A & P/A & P/A & P/A \\
Country & $\mathbf{1 9 8 1 - 1 9 8 5}$ & $\mathbf{1 9 8 6 - 1 9 9 0}$ & $\mathbf{1 9 9 1 - 1 9 9 5}$ & $\mathbf{1 9 9 6 - 2 0 0 0}$ & $\mathbf{2 0 0 1 - 2 0 0 5}$ \\
\hline Argentina & 1.039448 & 1.598482 & 0.886612 & 0.832340 & 0.989561 \\
Belgium & 1.050188 & 1.024373 & 0.986528 & 0.979599 & 0.973522 \\
Chile & -0.992120 & -4.236570 & 0.856029 & 0.619649 & 0.701454 \\
Egypt & 2.167789 & 1.760523 & 0.910669 & 0.770319 & 0.787597 \\
Greece & 1.126787 & 0.984882 & 1.069323 & 0.921356 & 0.965833 \\
Indonesia & 0.967483 & 1.050675 & 1.031292 & 0.989131 & 0.959071 \\
India & 0.978872 & 1.088846 & 1.047280 & 0.980618 & 0.949263 \\
Kenya & 1.000836 & 0.988388 & 1.024692 & 0.976068 & 0.991494 \\
Morocco & -9.145880 & 1.328307 & 0.946906 & 0.762457 & 0.760918 \\
Mexico & -1.971100 & 1.213400 & 0.916616 & 0.774724 & 0.699782 \\
Nigeria & 0.919757 & 2.258793 & 1.323212 & 0.888188 & 0.711915 \\
Portugal & 1.473655 & 0.901950 & 0.964633 & 0.909544 & 0.989794 \\
Saudi Arabia & 0.930882 & 1.040741 & 1.054994 & 1.016400 & 0.960106 \\
Turkey & 1.072415 & 1.058522 & 0.951905 & 1.003680 & 0.958160 \\
USA & 0.996086 & 1.005870 & 1.011281 & 0.998562 & 0.987697
\end{tabular}

Trade potential of Pakistan (regional). 
Table III: Countries with who Pakistan has Potential to Expand Trade

\begin{tabular}{|c|c|c|c|c|c|}
\hline $\begin{array}{l}\text { Indicator } \\
\text { Country }\end{array}$ & $\begin{array}{c}\text { P/A } \\
\text { 1981-1985 }\end{array}$ & $\begin{array}{c}\text { P/A } \\
1986-1990\end{array}$ & $\begin{array}{c}\text { P/A } \\
\text { 1991-1995 }\end{array}$ & $\begin{array}{c}\text { P/A } \\
1996-2000\end{array}$ & $\begin{array}{c}\text { P/A } \\
2001-2005\end{array}$ \\
\hline & \multicolumn{5}{|c|}{ EU } \\
\hline Austria & 1.137352578 & 0.811927666 & 0.837542096 & 1.427747973 & 1.053899939 \\
\hline Germany & 0.956291131 & 0.911936573 & 0.917830342 & 1.120323297 & 1.139212626 \\
\hline Denmark & 1.046771846 & 0.979300659 & 0.893445106 & 1.068050660 & 1.129264459 \\
\hline France & 1.075278625 & 0.965303431 & 0.760671856 & 1.080802043 & 1.280537206 \\
\hline Italy & 0.813051700 & 0.848087550 & 0.916447295 & 1.250994954 & 1.349956933 \\
\hline Norway & 0.817569979 & 0.666465863 & 1.078590371 & 1.237761598 & 1.508518330 \\
\hline Portugal & 1.999916579 & 0.720611725 & 1.110029763 & 0.753606950 & 1.042883248 \\
\hline Sweden & 0.908778030 & 0.891899212 & 0.909363766 & 1.146664050 & 1.319481570 \\
\hline Switzerland & 1.067237488 & 1.008497426 & 1.039562245 & 0.791418017 & 1.135657813 \\
\hline \multirow[t]{2}{*}{ UK } & 0.842590010 & 1.035062240 & 1.037817813 & 1.074609098 & 1.023935000 \\
\hline & \multicolumn{5}{|c|}{ SAARC and ECO } \\
\hline Bangladesh & 0.651011679 & 0.867632977 & 0.958304783 & 1.374974463 & 1.343115692 \\
\hline \multirow[t]{2}{*}{ Sri Lanka } & 2.366959506 & 1.563167369 & 2.443460076 & 2.193996173 & 2.900584151 \\
\hline & \multicolumn{5}{|c|}{ ASEAN } \\
\hline Malaysia & 0.321026926 & 0.492811044 & 0.444019338 & 0.780458303 & 1.018108863 \\
\hline Philippines & 4.571064951 & 1.814009985 & 2.544464428 & 5.190650879 & 5.155422358 \\
\hline \multirow[t]{2}{*}{ Thailand } & 1.204476902 & 0.614190674 & 1.271517063 & 1.423270454 & 1.509532946 \\
\hline & \multicolumn{5}{|c|}{ Far East } \\
\hline Japan & 0.769718288 & 0.794378051 & 0.835171339 & 1.301768109 & 1.618099785 \\
\hline Korea & 1.326792678 & 0.934921894 & 0.806914572 & 0.964802323 & 1.082680788 \\
\hline \multirow[t]{2}{*}{ New Zealand } & 1.085576993 & 0.909940355 & 1.031804338 & 1.042268727 & 1.074953076 \\
\hline & \multicolumn{5}{|c|}{ Middle East and Africa } \\
\hline \multirow[t]{2}{*}{ Kuwait } & 1.051205780 & 1.252295152 & 1.860353828 & 1.423054533 & 1.46985046 \\
\hline & \multicolumn{5}{|c|}{ Middle East and ECO } \\
\hline Iran & 0.523481128 & 0.853901156 & 1.182475844 & 2.212496279 & 1.715455747 \\
\hline \multirow[t]{2}{*}{ Kuwait } & 0.476750335 & 0.618405824 & 1.178113114 & 1.094131244 & 1.308258676 \\
\hline & \multicolumn{5}{|c|}{ NAFTA and Latin America } \\
\hline Argentina & 0.771210421 & 2.765037236 & 0.689690668 & 0.623510706 & 1.39733281 \\
\hline Brazil & 0.387620692 & 0.787571107 & 0.762031679 & 2.084614484 & 3.96390995 \\
\hline Canada & 0.525346794 & 0.794414999 & 0.854818865 & 1.408449260 & 1.88920301 \\
\hline USA & 0.593728446 & 0.814288330 & 1.037956884 & 1.337217831 & 1.62904177 \\
\hline
\end{tabular}


Table VI: Countries with who Pakistan had Exceeded Trade Potential by 2005

\begin{tabular}{lccccc}
\hline Indicator & P/A & P/A & P/A & P/A & P/A \\
Years & $\mathbf{1 9 8 1 - 1 9 8 5}$ & 1986-1990 & 1991-1995 & 1996-2000 & 2001-2005 \\
\hline Belgium & 1.260169467 & 1.19074882 & 1.002600752 & 0.842884658 & 0.753486494 \\
Spain & 1.097231991 & 1.013923649 & 1.0798564 & 0.954338095 & 0.952616063 \\
Greece & 1.367883153 & 1.047312378 & 1.482724998 & 0.719981764 & 0.825343529 \\
Netherlands & 1.264944669 & 1.051757815 & 0.987359263 & 0.873005253 & 0.889590229 \\
\hline \multicolumn{5}{c}{ SAARC and ECO } \\
\hline India & 1.26796084 & 1.581028029 & 1.153707044 & 0.785906964 & 0.689285169 \\
Iran & 0.263669565 & 0.450555685 & 0.516876316 & 0.836204633 & 0.490156948 \\
Turkey & 1.980332393 & 1.704443021 & 0.806042676 & 0.909256822 & 0.666102253 \\
\hline Indonesia & 0.620632473 & 0.615405727 & 0.482319405 & 0.492536709 & 0.377061895 \\
\hline Australia & 1.241984129 & 1.155999625 & 1.022908234 & 0.774045953 & 0.909932908 \\
China & 0.668249316 & 1.137310498 & 1.297735683 & 1.253607609 & 0.94242452 \\
Hong Kong & 1.547684528 & 1.486066886 & 0.801636384 & 0.668638696 & 0.892766943 \\
\hline \multicolumn{5}{c}{ Middle East and Africa } \\
\hline Saudi Arabia & 0.546601356 & 1.252716664 & 1.097234411 & 0.998447416 & 0.52637379 \\
Egypt & 2.954937604 & 3.708859830 & 0.498773969 & 0.317076989 & 0.24784587 \\
Morocco & 13.89190531 & 3.105595225 & 0 & 0.356611370 & 0.27012479 \\
Kenya & 1.108987311 & 1.268670782 & 1.034720320 & 0.757206628 & 0.90028363 \\
Nigeria & 1.076680337 & 2.757395352 & 1.989090417 & 0.791530685 & 0.41467701 \\
\hline Egypt & 2.982303776 & 3.314692612 & 0.769305621 & 0.451042419 & 0.486558988 \\
Saudi Arabia & 0.519078093 & 1.056457151 & 1.312033304 & 1.253256645 & 0.885965264 \\
Turkey & 1.261087539 & 1.439277996 & 0.812185409 & 1.052418036 & 0.884906846 \\
\hline Chile & 4.091255652 & 3.712814729 & 0.759661858 & 0.373914032 & 0.65177942 \\
\hline Mexico & 6.329781561 & 1.210942339 & 0.828703073 & 0.591419281 & 0.50868432 \\
\hline \multicolumn{5}{c}{ Middle East and ECO } \\
\hline
\end{tabular}




\section{References}

Achakzai, J.K. (2006). Intra-ECO Trade: A Potential Region for Pakistan's Future Trade. Pakistan Development Review, 45(3), 425-437.

Ahmed, S., and Ghani, E. (2007). South Asia's Growth and Regional Integration: An Overview. In South Asia: Growth and Regional Integration. Washington, DC: World Bank.

Anderson, J.E. (1979). A Theoretical Foundation for the Gravity Equation. American Economic Review, 69(1), 106-116.

Anderson, J.E., and van Wincoop, E. (2001). Border, Trade and Welfare. Working Paper 508. Boston, MA: Department of Economics, Boston College.

Baltagi, B.H. (2000). Econometric Analysis of Panel Data. Chapter 14. Englewood Cliffs, NJ: Prentice-Hall.

Baroncelli, E. (2007). The "Peace Dividend," SAFTA and Pakistan-India Trade. In Naqvi, Z.F. and Schuler, P. (Eds.), The Challenges and Potential of Pakistan-India Trade. Washington, DC: World Bank.

Batra, A. (2006). India's Global Trade Potential: The Gravity Model Approach. Global Economic Review, 35(3), 327-361.

Benedictis, L.De, and Vicarelli, C. (2004). Trade Potential in Gravity Panel Data Models. Berkeley Electronic Journal of Economic Analysis and Policy, 5(1).

Bergstrand, J.H. (1985). The Gravity Equation in International Trade: Some Microeconomic Foundations and Empirical Evidence. Review of Economics and Statistics, 67(3), 474-481.

Bergstrand, J.H. (1989). The Generalized Gravity Equation, Monopolistic Competition and the Factor-Proportions Theory in International Trade. Review of Economics and Statistics, 71(1), 143-153.

Bergstrand, J.H. (1990). The Heckscher-Ohlin-Samuelson Model, the Linder Hypothesis and the Determinants of Bilateral Intra-Industry Trade. Economic Journal, 100(403), 1216-1229.

Boris, V., and Vedran, S. (2002). SEE and the Trade Potential of Croatia. Retrieved from www.wiiw.ac.at/balkan/files/Vujcic+Sosic.pdf 
Burfisher, M.E., and Zahniser, S. (2001). Multilateralism and Regionalism: Dual Strategies for Trade Reform. In Mary E. Burfisher (Ed.), Agricultural Policy Reform in the WTO: The Road Ahead. Agricultural Economic Report 802. Washington, DC: United States Department of Agriculture/Economic Research Service.

Bussiere, M., and Schnatz, B. (2006). Evaluating China's Integration in World Trade with a Gravity Model based Benchmark. Working Paper 693. Frankfurt: European Central Bank.

Carrillo, C., and Li, C.A. (2002). Trade Blocks and the Gravity Model: Evidence from Latin American Countries. Economics Discussion Paper 542. UK: Department of Economics, University of Essex.

Cernat, L. (2001). Assessing Regional Trade Arrangements: Are SouthSouth RTAs more Trade Diverting? Policy Issues in International Trade and Commodities, Study Series 16. Geneva: United Nations Conference on Trade and Development.

Clarete, R., Edmonda, C., and Wallack, J.S. (2002). Asian Regionalism and its Effects on Trade in the 1980s and 1990s. Economics and Research Department Working Paper 30. Manila: Asian Development Bank.

Deordorff, A.V. (1995). Determinants of Bilateral Trade: Does Gravity Work in a Neo-Classical World? Working Paper W5377. Cambridge, MA: National Bureau of Economic Research.

Egger, Peter. (2002). An Econometric View on the Estimation of Gravity Models and the Calculation of Trade Potentials. The World Economy, 25, 297-312.

Feenstra, R.C., Markusen, J.R., and Rose, A.K. (1998). Understanding the Home Market Effect and the Gravity Equation: The Role of Differentiated Goods. Working Paper 6804. Cambridge, MA: National Bureau of Economic Research.

Government of Pakistan. Pakistan Economic Survey 2006-07. Islamabad: Ministry of Finance.

Government of Pakistan. Various Documents on Trade Policy. Islamabad: Ministry of Commerce. 
Greenaway, D., and Milner, C. (2002). Regionalism and Gravity. Scottish Journal of Political Economy, 49, 574-585.

Gujrati, D.N. (2003). Panel Data Regression Models. In Basic Econometrics (4th ed.). New York: McGraw-Hill.

Harris, M.N., and Matyas, L. (1998). The Econometrics of Gravity Models. Working Paper 5. Melbourne: University of Melbourne, Melbourne Institute of Applied Economic and Social Research.

Head, K. (2000). Gravity for Beginners. Vancouver: University of British Columbia, Faculty of Commerce.

Helmers, C., and Pasteels, J.M. (2005). TradeSim (Third Version): A Gravity Model for the Calculation of Trade Potentials for Developing Countries and Economies in Transition. Geneva: International Trade Centre.

Helpman, E., and Krugman, P.R. (1985). Market Structure and Foreign Trade: Increasing Returns, Imperfect Competition, and the International Economy. Cambridge, MA: Massachusetts Institute of Technology.

Kalbasi, H. (2001). The Gravity Model and Global Trade Flows. Isfahan: University of Isfahan, Department of Economics.

Kazmi, Sajid. (2006). Market Access through Free Trade Agreements: Pakistan's Experience. Sustainable Development Policy Institute Research and News Bulletin, 13(4-5).

Khan, A.H., and Mahmood, Z. (2000). Pakistan and Emerging Global Trading Environment. Lahore: Vanguard Books.

Koukhartchouk, O., and Mauref, M. (2003). Accession to the WTO and EU Enlargement: What potential for Trade Increase? Centre for Economic Policy Research Discussion Paper 3944. Paris: Université Paris.

Kumar, A. (2006). Pakistan and Bangladesh delay SAFTA Take Off. South Asia Analysis Group Paper 1891. Retrieved from http:// www.southasiaanalysis.org/\%5Cpapers19\%5Cpaper1891. html

Kumar, A. (2006). China-Pakistan Economic Relations. Special Report 30. New Delhi: Institute of Peace and Conflict Studies. 
Leamer, E.E. (1974). The Commodity Composition of International Trade in Manufactures: An Empirical Analysis. Oxford Economic Papers, 26.

Leamer, E.E., and Stern, Robert, M. (1970). Quantitative International Economics. Journal of International Economics, 1(3), 359-361.

Linnemann, H. (1966). Modeling International Trade Flows: An Econometric Approach. Amsterdam: North-Holland.

Ozdeser, H., and Dizen, E. (2010). Turkey's Trade Potential with EuroZone Countries: A Gravity Study. European Journal of Scientific Research, 43(1).

Paas, T. (2002). Regional Integration of International Trade in the Context of EU Eastward Enlargement. Discussion Paper 218. Hamburg: Hamburgisches Welt-Wirtschafts-Archiv.

Poyhonen, P. (1963). A Tentative Model for the Volume of Trade between Countries. Weltwirtschaftliches Archiv, 90, 93-100.

Rahman, M.M. (2003). A Panel Analysis of Bangladesh's Trade: The Gravity Model Approach. Sydney: University of Sydney.

Rahman, M., Shadat, W.B., and Das, N.C. (2006). Trade Potential in SAFTA: An Application of Augmented Gravity Model. Paper 61. Dhaka: Centre for Policy Dialogue.

Sayal, H.N. (2007). Pakistan and Malaysia Trade Relations. Retrieved from http://www.issi.org.pk/journal/2007_files/no 1/article/al.htm)

Sen, A., and Siddiqui, H. (2006). India, ASEAN Toiling for Pact on Negative Items under FTA. Retrieved from http:/ / www.bilaterals.org/ article.php3?id_article $=3850$ )

Simwaka, K. (2006). Dynamics of Malawi's Trade Flows: A Gravity Model Approach. Munich Personal RePEc Archive Paper. Munich: University Library of Munich.

Soderling, L. (2005). Is the Middle East and North Africa Region Achieving its Trade Potential? Washington, DC: International Monetary Fund, Middle East and Central Asia Department. 
Soloaga, I., and Winters, A.L. (2001). Regionalism in the Nineties: What Effects on Trade? North American Journal of Economics and Finance, 12(1), 1-29.

South Asian Association for Regional Cooperation. Charter of Democracy. Retrieved from http:/ / www.saarcsec.org/ main.php?id=10\&t=3.2

State Bank of Pakistan. (2005). Special Section 7.5: Pakistan's Export Potential: A Gravity Model Analysis. In Annual Report 2004-05. Karachi: Author.

Subramanian, A., and Wei, S.J. (2003). The WTO Promotes Trade, Strongly but Unevenly. Discussion Paper 5122. London: Centre for Economic Policy Research.

Thapar, R. (2006). SAARC: Ineffective in Promoting Economic Cooperation in South Asia. Stanford Journal of International Relations, 7(1).

Tinbergen, J. (1962). An Analysis of World Trade Flows. In Shaping the World Economy: Suggestions for an International Economic Policy. New York: The Twentieth Century Fund.

Wasam, H.S. (2003). From SAPTA to SAFTA: Gravity Analysis of South Asian Free Trade. Sri Lanka: University of Sri Jayewardenepura.

World Bank. (2007). World Economy Gravity Models. In World Development Indicators. [CD-ROM]. 